\title{
ANALISIS FAKTOR-FAKTOR YANG MEMPENGARUHI PRODUKSI INDUSTRI KECIL OLAHAN IKAN DI KOTA MANADO
}

\author{
Zisca Veybe sumolang, Tri Oldy Rotinsulu, Daisy S.M. Engka \\ Fakultas Ekonomi dan Bisnis, Program Magister Ilmu Ekonomi \\ Universitas Sam Ratulangi
}

\begin{abstract}
ABSTRAK
Tujuan penelitian ini untuk mengetahui pengaruh modal kerja, bahan baku, tenaga kerja serta pasar terhadap produksi industri kecil olahan ikan di Kota Manado. Metode pengolahan data adalah analisis kuantitatif. Penelitian dilakukan pada pengusaha industri kecil olahan ikan di Kota Manado. Jumlah responden adalah 30 orang. Alat analisis penelitian menggunakan analisis regresi berganda dengan teknik ordinary least squares.

Produksi industri kecil (PIK) penting dalam peningkatan perekonomian suatu daerah di Indonesia. Produksi industri kecil yang tinggi menandakan terjadinya efisiensi dari industri yang melakukan proses manufaktur input, proses dan output sumber-sumber daya yang ada. Hal ini mengandung implikasi agar dapat dilakukan peningkatan secara bersama-sama dari keempat faktor tadi agar produksi industri kecil olahan ikan di Kota Manado dapat terus meningkat.
\end{abstract}

Kata-Kata Kunci:: Modal Kerja, Bahan Baku, Tenaga Kerja, Pasar, Produksi, Industri Kecil, Olahan Ikan

\begin{abstract}
The purpose of this study to determine the effect of working capital, raw materials, labor and markets on the production of small fish processing industry in Manado City. Data processing method is a quantitative analysis. The research was conducted on small scale business of fish processing industry in Manado City. The number of respondents is 30 peoples. The research tool used multiple regression analysis with ordinary least squares technique.

Small industrial production (PIK) is important in improving the economy of a region in Indonesia. High production of small industries signifies the efficiency of industries that process input manufacturing, process and output of existing resources. This has implications for the joint increase of these four factors so that the production of small processed fish industry in Manado City can continue to increase.
\end{abstract}

Key Words: Working Capital, Raw Materials, Labor, Market, Production, Small Industry, Processed Fish 


\section{Latar Belakang Permasalahan}

\section{PENDAHULUAN}

Pembangunan ekonomi merupakan salah satu pilar penting bagi suatu bangsa. Jika pembangunan ekonomi berhasil, maka bidang-bidang lainnya seperti bidang hukum, bidang politik, bidang pertanian, dan lain-lain juga akan sangat terbantu. Pembangunan ekonomi yang berhasil pada suatu negara ditandai antara lain dengan tingginya pendapatan perkapita masyarakat negara tersebut. Dengan tingginya pendapatan perkapita masyarakat, maka negara dan masyarakat akan mampu memenuhi berbagai kebutuhan dalam berbagai bidang lainnya.

Salah satu sektor yang berperan penting dalam pembangunan ekonomi suatu negara adalah sektor industri pengolahan. Peranan sektor industri pengolahan dalam pembangunan ekonomi dapat ditelusuri dari kontribusi msing-masing subsektor terhadap laju pertumbuhan ekonomi nasional atau terhadap produk domestik bruto (PDB). Pada negara-negara yang sudah tergolong maju, peranan sektor industri dalam pembangunan ekonomi lebih dominan dibandingkan sektor pertanian. Bahkan sektor industri memegang peranan kunci sebagai mesin pembangunan ekonomi karena sektor industri memiliki beragam keunggulan dibandingkan sektor lain, seperti kapitalisasi modal yang tertanam sangat besar, kemampuan menyerap tenaga kerja yang besar, kemampuan menciptakan nilai tambah (value added creation) dari setiap input atau bahan dasar yang diolah. Pada negara-negara berkembang, peranan sektor industri juga menunjukkan kontribusi yang semakin tinggi. Kontribusi yang semakin tinggi dari sektor industri terhadap pembangunan ekonomi suatu negara menyebabkan perubahan struktur perekonomian negara yang bersangkutan secara perlahan ataupun cepat dari sektor pertanian ke sektor industri.

Sektor Industri di Indonesia memiliki visi pembangunan Industri Nasional sebagaimana yang tercantum dalam Peraturan Presiden Nomor 28 Tahun 2008 tentang Kebijakan Industri Nasional, yaitu menjadikan Indonesia menjadi Negara Industri Tangguh pada tahun 2025, dengan visi antara pada tahun 2020 sebagai Negara Industri Maju Baru. Hal ini sesuai dengan Deklarasi Bogor tahun 1995 antar para kepala Negara APEC bahwa pada tahun tersebut liberalisasi di negara-negara APEC sudah harus terwujud.

Untuk mewujudkan target-target tersebut, diperlukan upaya-upaya terstruktur dan terukur, yang harus dijabarkan ke dalam peta strategi yang mengakomodasi keinginan pemangku kepentingan berupa strategic outcomes yang terdiri dari: 1) Meningkatnya nilai tambah industri, 2) Meningkatnya penguasaan pasar dalam dan luar negeri, 3) Kokohnya faktor-faktor penunjang pengembangan industri, 4) Meningkatnya kemampuan inovasi dan penguasaan teknologi industri yang hemat energi dan ramah lingkungan, 5) Menguat dan lengkapnya struktur industri, 6) Meningkatnya persebaran pembangunan industri, serta 7) Meningkatnya peran industri kecil dan menengah terhadap PDB. Sektor industri sebagai salah satu motor penggerak perekonomian nasional Indonesia, menempatkan sektor industri pengolahan sebagai penggerak utama sektor ekonomi riil. Hal ini berkaitan dengan kekayaan sumber daya alam Indonesia yang memiliki keunggulan komparatif berupa produk primer yang perlu diolah menjadi produk industri untuk mendapatkan nilai tambah yang lebih tinggi. Sesuai dengan tahapan perkembangan negara Indonesia, sudah waktunya Indonesia melakukan pergerseran andalan sektor ekonomi Indonesia dari industri primer ke industri sekunder khususnya industri manufaktur non migas. Membangun sektor industri di era sekarang ini tentu membutuhkan strategi yang tepat dan konsisten, sehingga dapat mewujudkan industri yang tangguh dan berdaya saing baik di pasar domestik maupun di pasar global, yang pada gilirannya mampu mendorong tumbuhnya perekonomian, menciptakan lapangan kerja, meningkatkan pendapatan masyarakat dan akhirnya mengurangi kemiskinan. 
Sulawesi Utara khususnya Kota Manado merupakan salah satu wilayah di Indonesia yang memiliki potensi dan keunggulan ekonomis berupa kekayaan sumber daya alam dalam bidang pertanian, perikanan serta pariwisata. Untuk itu Manado layak untuk mengembangkan industri kecil dan menengah khususnya industri primer dan lebih khusus lagi industri sekunder yang melakukan pengolahan lebih lanjut kekayaan alam menjadi produk-produk yang lebih memiliki nilai tambah seperti pengolahan ikan.

Dalam Tabel 1 disajikan data industri kecil dan menengah di Propinsi Sulawesi Utara.

\section{Tabel 1. Data Penambahan Industri Kecil dan Menengah di Sulawesi Utara tahun 2015}

\begin{tabular}{|l|r|r|r|r|}
\hline \multicolumn{1}{|c|}{ Cabang Industri } & $\begin{array}{c}\text { Unit } \\
\text { Usaha } \\
\text { (Unit) }\end{array}$ & Tenaga Kerja & $\begin{array}{c}\text { Nilai } \\
\text { Investasi (Rp, } \\
\text { Ribu) }\end{array}$ & $\begin{array}{c}\text { Nilai } \\
\text { Produksi } \\
\text { (Rp, Ribu) }\end{array}$ \\
\hline Pangan & 736 & 1671 & 18.394 .941 & 28.530 .436 \\
\hline Sandang & 166 & 167 & 906.630 & 6.386 .230 \\
\hline $\begin{array}{l}\text { Kimia dan Bahan } \\
\text { Bangunan }\end{array}$ & 151 & 654 & 11.240 .147 & 39.535 .709 \\
\hline $\begin{array}{l}\text { Logam dan } \\
\text { Eloktronika }\end{array}$ & 241 & 317 & 1.948 .625 & 14.635 .920 \\
\hline Kerajinan & 77 & & 556.844 & 2.417 .300 \\
\hline
\end{tabular}

Sumber: Data BPS (2016)

Berdasarkan data pada Tabel 1 terlihat bahwa Industri Kecil dan Menengah di cabang Industri Pangan memiliki peran yang cukup penting bagi perekonomian Sulawesi Utara. Hal ini dapat dilihat dari kontribusinya terhadap penciptaan lapangan kerja lewat unit usaha yang ada yaitu sebanyak 736 unit usaha, dengan penyerapan tenaga

Berdasarkan pendapat para ahli, ada beberapa indikator yang menyebabkan industri kecil ini dapat berkembang dengan baik. Faktor pertama adalah modal kerja. Menurut Bilias (2008:23) menyatakan bahwa modal kerja sangat berpengaruh terhadap berjalannya operasi suatu perusahaan sehingga modal kerja harus senantiasa tersedia dan terus-menerus diperlukan bagi kelancaran usaha, dengan modal yang cukup akan dapat dihasilkan produksi, yang optimal dan apabila dilakukan penambahan modal maka produksi akan meningkat lebih besar lagi. Faktor kedua adalah bahan baku. Assauri (2000:15) produksi adalah semua kegiatan dalam menciptakan dan menambah kegunaan suatu barang atau jasa. Faktor ketiga adalah tenaga kerja. Menurut Case \& Fair, (2007:144) tenaga kerja merupakan elemen yang cukup penting dalam kegiatan operasi suatu perusahaan. Faktor keempat adalah pasar, dimana menurut Bilas (2008), pasar merupakan salah satu hal penting yang harus diperhatikan, karena mempengaruhi tingkat produksi suatu industri kecil.

Berdasarkan uraian latar belakang dan data-data diatas, penulis tertarik untuk mengadakan penelitian mengenai faktor-faktor yang mempengaruhi produksi industri kecil olahan ikan di Kota Manado.

\section{Rumusan Masalah}

Rumusan dalam penelitian ini adalah sebagai berikut :

Bagaimana pengaruh modal kerja, bahan baku, tenaga kerja dan pasar terhadap produksi industri kecil olahan ikan di Kota Manado? 


\section{Tujuan Penelitian}

Berdasarkan rumusan masalah tersebut di atas, dapat dirumuskan tujuan penelitian yaitu:

Untuk mengetahui pengaruh modal kerja, bahan baku, tenaga kerja dan pasar terhadap produksi industri kecil olahan ikan di Kota Manado.

\section{Manfaat Penelitian}

Penelitian ini diharapkan dapat memberikan manfaat sebagai berikut:

1. Untuk memberikan gambaran mengenai faktor-faktor yang dominan mempengaruhi produksi industri kecil olahan ikan di Kota Manado;

2. Untuk menjadikan masukan pihak yang terkait dengan produksi industri kecil olahan khususnya olahan ikan di Kota Manado;

3. Untuk menambah khasanah ilmu pengetahuan terutama mengenai alternatif industri kecil khususnya industri maritim untuk menunjang program pariwisata dan program Nawacita di Manado, Sulawesi Utara dan Indonesia;

4. Untuk memberikan gambaran bagi masyarakat luas mengenai berbagai faktor yang berpengaruh terhadap produksi industri kecil di Manado khususnya industri olahan ikan.

5. Untuk memberikan informasi kepada pemerintah daerah tentang pengaruh industri kecil terhadap peningkatan perekonomian daerah khususnya produksi industri kecil.

6. Untuk memberikan gambaran kepada investor/eksportir/produsen tentang perkembangan industri pengolahan ikan di Kota Manado.

\section{Landasan Teori \\ Teori Produksi \\ Pengertian Produksi}

KERANGKA TEORITIS

Produksi adalah menciptakan, menghasilkan, dan membuat. Kegiatan produksi tidak akan dapat dilakukan kalau tidak ada bahan yang memungkinkan dilakukannya proses produksi itu sendiri. Untuk bisa melakukan produksi, orang memerlukan tenaga manusia, sumber-sumber alam, modal dalam segala bentuknya, serta kecakapan. Semua unsur itu disebut faktor-faktor produksi (factors of production). Jadi, semua unsur yang menopang usaha penciptaan nilai atau usaha memperbesar nilai barang disebut sebagai faktor-faktor produksi.

\section{Fungsi Produksi}

Fungsi produksi adalah suatu persamaan yang menunjukkan jumlah maksimum output yang dihasilkan dengan kombinasi input tertentu (Ferguson dan Gould, 1975:345). Fungsi produksi menunjukkan sifat hubungan di antara faktor-faktor produksi dan tingkat produksi yang dihasilkan. Faktor-faktor produksi dikenal pula dengan istilah input dan jumlah produksi selalu juga disebut sebagai output. Fungsi produksi selalu dinyatakan dalam rumus seperti berikut (Sukirno, 2010):

$$
Q=f(K, L, R, T)
$$

\section{Fungsi Produksi Cobb-Douglas}

Fungsi produksi Cobb Douglas merupakan contoh produksi yang homogen yang mempunyai substitusi yang konstan. Fungsi produksi Cobb Douglas dapat dituliskan sebagai berikut (Nicholson, 1995:332) : 


$$
\mathrm{Q}=\mathrm{AKa} \mathrm{Lb}
$$

Di mana :

$\mathrm{Q}=$ output

$\mathrm{A}=$ konstanta yang mempunyai angka positif dan koefisien teknologi

$\mathrm{K}=$ modal

L=tenaga kerja

a dan $b=$ menunjukkan skala ke hasil atau dengan menarik log dari kedua ruas persamaan fungsi produksi, maka :

$$
\log \mathrm{Q}=\log \mathrm{A}+\alpha \log \mathrm{K}+\beta \log \mathrm{L}+\varepsilon
$$

Fungsi produksi Cobb Douglas mempunyai ciri-ciri : kombinasi inputnya efisiensi secara teknis, ada input tetap, dan tunduk pada The Law of Diminishing Return (Arsyad, 2010).

\section{Variabel-Variabel yang Mempengaruhi Produksi Industri Kecil \\ - Modal Kerja}

Setiap perusahaan perlu menyediakan modal kerja untuk membelanjai operasi

perusahaan dari hari ke hari seperti misalnya untuk memberi uang muka pada pembelian bahan baku atau barang dagangan, membayar upah buruh dan gaji pegawai serta biaya-biaya lainnya. Sejumlah dana yang dikeluarkan untuk membelanjai operasi perusahaan tersebut diharapkan akan kembali lagi masuk dalam perusahaan dalam jangka waktu pendek melalui hasil penjualan barang dagangan atau hasil produksinya. Uang yang masuk yang bersumber dari hasil penjualan barang dagangan tersebut akan dikeluarkan kembali guna membiayai operasi perusahaan selanjutnya.

\section{- Bahan Baku}

Menurut Mulyadi (2005;275) bahan baku adalah :

"Bahan baku merupakan bahan yang memebentuk bagian menyeluruh".

Menurut Masiyal Kholmi (2003;29) bahan baku adalah :

" Bahan baku merupakan bahan yang membentuk bagian besar produk jadi, bahan baku yang diolah dalam perusahaan manufaktur dapat diperoleh dari pembelian lokal, impor atau hasil pengolahan sendiri”.

Sedangkan menurut Suyadi Prawirosentono (2001;61) bahan baku adalah :

"Bahan baku adalah bahan utama dari suatu produk atau barang".

\section{- Tenaga Kerja}

Tenaga kerja merupakan istilah yang identik dengan istilah personalia, di dalamnya meliputi buruh. Buruh yang dimaksud adalah mereka yang bekerja pada usaha perorangan dan diberikan imbalan kerja secara harian maupun borongan sesuai dengan kesepakatan kedua belah pihak, biasanya imbalan kerja tersebut diberikan secara harian (Siswanto, 1989: 9). Selain itu juga, pengertian tenaga kerja menurut BPS adalah salah satu moda bagi geraknya roda pembangunan. Jumlah dan komposisi tenaga kerja selalu mengalami perubahan seiring dengan berlangsungnya dinamika penduduk. Ketidakseimbangan antara jumlah angkatan dan lowongan kerja yang tersedia menyebabkan timbulnya masalah-masalah sosial.

\section{- Pasar}

Secara umum pasar adalah suatu tempat atau proses interaksi antara permintaan (pembelian) dan penawaran (penjualan) dari suatu barang atau jasa tertentu, sehingga akhirnya dapat menetapkan harga keseimbangan (harga pasar) dan jumlah yang diperdagangkan (Suprayitno, 2008). 


\section{Konsep Ekonomi Pembangunan}

Mengenai pengertian pembangunan, para ahli memberikan definisi yang bermacammacam. Istilah pembangunan bisa saja diartikan berbeda antara satu orang dengan orang lainnya, negara yang satu dengan negara yang lainnya. Namun secara umum terdapat satu kesepakatan bahwa pembangunan merupakan proses untuk melakukan perubahan (Riyadi dan Bratakusumah, 2005).

\section{Konsep Industri}

Industri Pengolahan (BPS, 2017) adalah suatu kegiatan ekonomi yang melakukan kegiatan mengubah suatu barang dasar secara mekanis, kimia, atau dengan tangan sehingga menjadi barang jadi/setengah jadi, dan atau barang yang kurang nilainya menjadi barang yang lebih tinggi nilainya, dan sifatnya lebih dekat kepada pemakai akhir. Termasuk dalam kegiatan ini adalah jasa industri/makloon dan pekerjaan perakitan (assembling).

\section{Industri Kecil dan Menengah}

Industri adalah kegiatan untuk mengubah bahan baku menjadi barang jadi yang lebih tinggi nilainya (Rhodant, dalam Sigit Pranoto, 2008). Industri kecil sebagai usaha produktif, terutama dalam bidang produksi atau bidang jasa-jasa misalnya transportasi, atau jasa perhubungan yang menggunakan modal dan tenaga kerja dalam jumlah yang relatif kecil (Winardi, dalam Sigit Pranoto, 2008). Industri kecil dan Menengah (IKM) adalah kelompok usaha yang mampu menyerap banyak tenaga kerja dan menjadi sumber pendapatan masyarakat (Nurhayati, dkk, 2012).

\section{Konsep Industri Kecil}

Industri kecil adalah kegiatan industri yang dikerjakan di rumah-rumah penduduk yang pekerjanya merupakan anggota keluarga sendiri yang tidak terikat jam kerja dan tempat. Industri kecil dapat juga diartikan sebagai usaha produktif diluar usaha pertanian, baik itu merupakan mata pencaharian utama maupun sampingan (Tambunan, 1999). Industri kecil merupakan industri yang berskala kecil dan industri rumah tangga yang diusahakan untuk menambah pendapatan keluarga. Menurut data BPS industri kecil merupakan industri dengan tenaga kerja antara 5-19 orang.

\section{Teori Ekonomi Lokal}

Pembangunan ekonomi lokal dimaksudkan untuk menggambarkan proses dimana pemerintah daerah maupun masyarakat mengorganisir aktifitas bisnis maupun lapangan kerja untuk tujuan bersama. Tujuan dari pembangunan ekonomi lokal adalah untuk memberikan kesempatan kerja serta mampu memperbaiki masyarakat dengan menggunakan sumber daya yang ada. 


\section{Kerangka Berpikir}

\section{Gambar 1 Kerangka Berpikir}

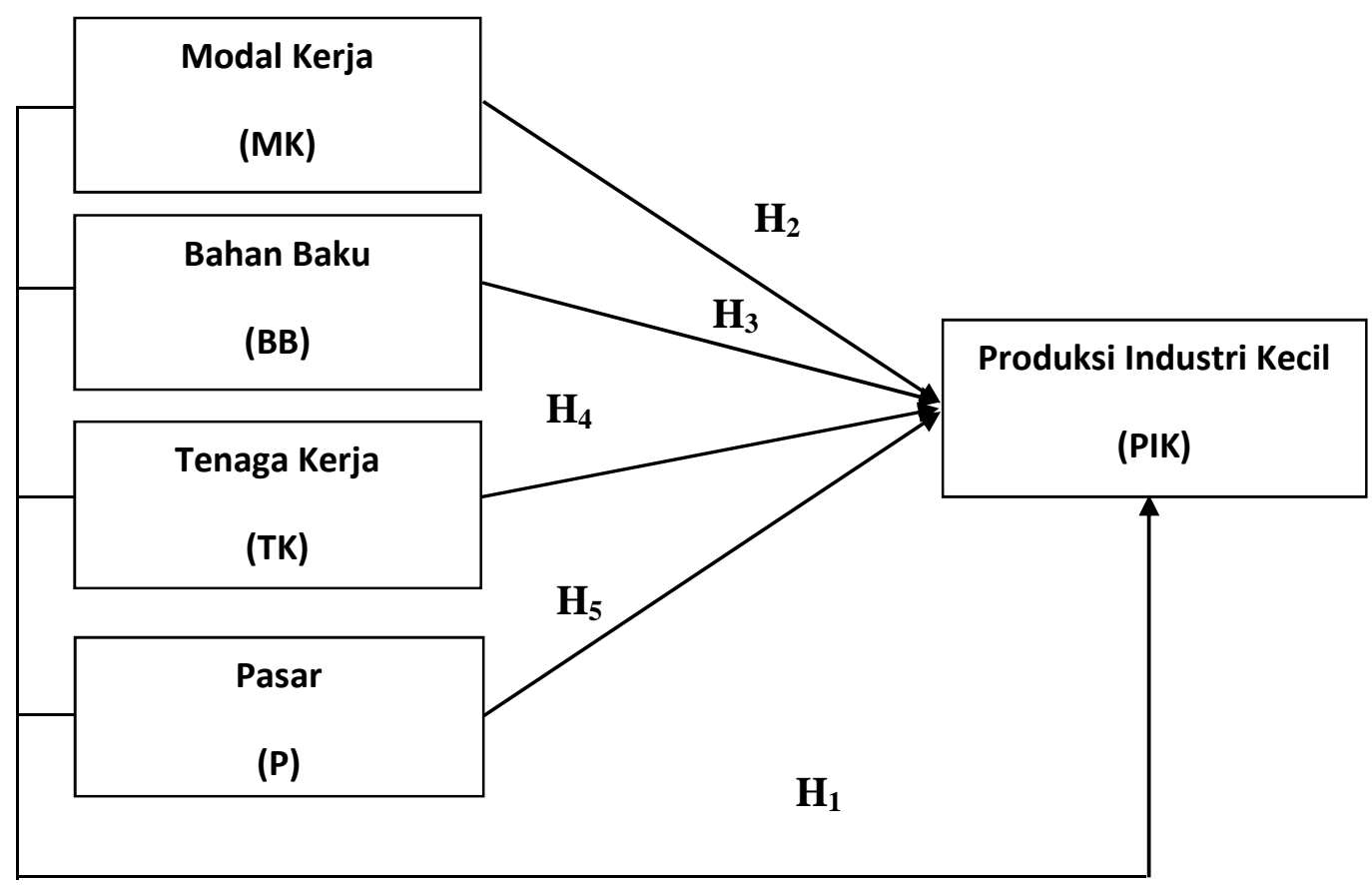

Berdasarkan Gambar 1 terlihat bahwa variabel independen terdiri dari modal kerja (MK), bahan baku (BB), tenaga kerja (TK) dan pasar (P), sedangkan variabel dependen yaitu produksi industri kecil (PIK).

\section{Hipotesis}

Untuk menjawab permasalahan sesuai dengan tujuan penelitian dan berdasarkan tinjauan pustaka serta landasan teoritis maka diajukan hipotesis sebagai berikut:

1. Diduga modal kerja, bahan baku, tenaga kerja serta pasar berpengaruh positif terhadap produksi industri kecil.

2. Diduga modal kerja berpengaruh positif terhadap produksi industri kecil;

3. Diduga bahan baku berpengaruh positif terhadap produksi industri kecil.

4. Diduga tenaga kerja berpengaruh positif terhadap produksi industri kecil.

Diduga pasar berpengaruh positif terhadap produksi industri kecil.

\section{Data dan Sumber Data}

\section{METODE PENELITIAN}

Data yang digunakan dalam penelitian ini merupakan data primer yang diambil dari responden penelitian. Data ini diambil dari lapangan yaitu pengusaha industri kecil olahan ikan di Kota Manado sebanyak 30 orang Responden. Pengambilan data dilakukan dengan membagikan kuesioner yang disebar kepada para responden pengusaha industri kecil olahan ikan di Kota Manado. 


\section{Metode Pengolahan Data}

Penelitian ini dilakukan dengan menggunakan analisis kuantitatif. Analisis kuantitatifnya digunakan model ekonometrika analisis regresi untuk mencerminkan hasil dan pembahasan yang dinyatakan dalam angka. Selain itu data diambil dari studi literatur melalui artikel, buku-buku dan hasil-hasil penelitian yang berhubungan dengan produksi industri kecil olahan ikan di kota Manado.

\section{Definisi Operasional Variabel}

Definisi operasional variabel adalah suatu definisi yang diberikan pada suatu variabel atau dengan cara memberikan arti atau menspesifikasikan kegiatan ataupun membenarkan suatu operasional yang diperlukan untuk mengukur variabel tersebut. Variabel terikat (Dependent Variabel) dalam penelitian ini adalah Produksi Industri Kecil dan variabel bebas (Independent Variabel) adalah Modal Kerja, Bahan Baku, Tenaga Kerja, dan Pasar.

Definisi operasional variabel dalam penelitian ini sebagai berikut:

1. Produksi Industri Kecil (PIK) adalah: hasil akhir dari proses atau aktivitas ekonomi dengan memanfaatkan beberapa masukan atau input yaitu dari industri kecil olahan ikan di Kota Manado.

2. Modal Kerja (MK) adalah: dana yang harus tersedia untuk membiayai kegiatan operasi perusahaan sehari-hari dari usaha industri kecil olahan ikan.

3. Bahan Baku (BB) adalah: bahan utama dari suatu produk atau barang dalam hal ini bahan baku utama dari olahan ikan adalah ikan laut.

4. Tenaga Kerja (TK) adalah: mereka yang bekerja pada usaha perorangan dan diberikan imbalan kerja secara harian maupun borongan sesuai dengan kesepakatan kedua belah pihak, biasanya imbalan kerja tersebut diberikan secara harian. Tenaga kerja dari industri olahan ikan adalah tenaga kerja yang bekerja langsung dalam memproduksi produk olahan ikan dari industri kecil di Kota Manado.

5. Pasar (P) adalah: suatu tempat atau proses interaksi antara permintaan (pembelian) dan penawaran (penjualan) dari suatu barang atau jasa tertentu, sehingga akhirnya dapat menetapkan harga keseimbangan (harga pasar) dan jumlah yang diperdagangkan. Pasar bagi produksi industri olahan ikan adalah pasar tradisional dan modern yang membantu mendistribusikan produk olahan ikan dari industri kecil di Kota Manado.

\section{Metode Analisis}

Metode analisis yang digunakan adalah analisis kuantitatif, yaitu dengan menggunakan model ekonometrika dengan bantuan program SPSS dan Microsoft Excel.

\section{Model Ekonometrika}

Alat analisis yang digunakan dalam penelitian ini adalah regresi berganda (multiple regression). Teknik yang digunakan untuk mencari nilai persamaan regresi yaitu dengan analisis Ordinary Least Squares (OLS).

Fungsi produksi yang digunakan dalam penelitian hasil produksi

industri kecil di Kabupaten Manado adalah sebagai berikut :

$\log \mathrm{PIK}=\log \mathrm{A}+\beta 1 \log \mathrm{MK}+\beta 2 \log \mathrm{BB}+\beta 3 \log \mathrm{TK}+\beta 4 \log \mathrm{P}+\varepsilon \ldots$ (1)

Keterangan:

PIK = Produksi industri kecil

$\mathrm{A}=$ intersept 


$$
\begin{aligned}
& \mathrm{MK}=\text { modal kerja } \\
& \mathrm{BB}=\text { bahan baku } \\
& \mathrm{TK}=\text { tenaga kerja } \\
& \mathrm{P}=\text { pasar } \\
& \beta=\text { parameter yang ditaksir } \\
& \varepsilon=\text { variabel pengganggu } \\
& \text { (disturbance term) }
\end{aligned}
$$

\section{Uji Asumsi Klasik}

Untuk memperoleh hasil regresi linier yang baik serta tidak bias maka perlu dilakukan uji asumsi klasik, yaitu: uji multikolinearitas, uji heteroskedastisitas, uji normalitas.

\section{Uji Multikolinearitas}

Uji multikolinearitas bertujuan untuk menguji apakah model regresi ditemukan adanya korelasi antar variabel bebas. Model regresi yang baik seharusnya tidak terjadi korelasi di antara variabel independen (Ghozali, 2011). Suatu analisis statistik dikatakan tidak terjadi gejala multikolinearitas jika nilai VIF (Variance Inflation Factor) < 10(Ghozali, 2011)..

\section{Uji Heteroskedastisitas}

Uji heteroskedastisitas bertujuan menguji apakah dalam model regresi terjadi ketidaksamaan varians dari residual satu pengamatan ke pengamatan yang lain. Jika varians dari residual satu pengamatan ke pengamatan lain tetap, maka disebut Homoskedastisitas dan jika berbeda disebut Heteroskedastisitas. Model regresi yang baik adalah yang Homoskedastisitas atau tidak terjadi Heteroskedastisitas (Ghozali, 2011).

\section{Uji Normalitas}

Uji normalitas bertujuan untuk menguji apakah dalam model regresi, variabel pengganggu atau residual memiliki distribusi normal (Ghozali, 2011). Cara termudah untuk melihat normalitas residual adalah dengan melihat grafik histogram yang membandingkan antara data observasi dengan distribusi yang mendekati distribusi normal. Distribusi normal akan membentuk satu garis lurus diagonal, dan ploting data residual akan dibandingkan dengan garis diagonal. Jika distribusi data residual normal, maka garis yang menggambarkan data sesungguhnya akan mengikuti garis diagonalnya (Ghozali, 2011).

\section{Uji Hipotesis}

Ketepatan fungsi regresi sampel dalam menaksir nilai aktual dapat diukur dari Goodness of Fitnya. Secara statistik, setidaknya ini dapat diukur dari nilai koefisien determinasi, nilai statistik F dan nilai statistik t. Perhitungan statistik disebut signifikan secara statistik apabila nilai uji statistiknya berada dalam daerah kritis (daerah dimana Ho ditolak). Sebaliknya disebut tidak signifikan bila nilai uji statistiknya berada dalam daerah dimana Ho diterima (Gujarati, 2003). 
Hasil Penelitian

\section{HASIL PENELITIAN DAN PEMBAHASAN}

Uji Asumsi Klasik

Uji Asumsi Klasik Normalitas

Gambar 2 berikut merupakan uji asumsi klasik normalitas yang diuji menggunakan program SPSS.

\section{Gambar 2 Uji Normalitas}

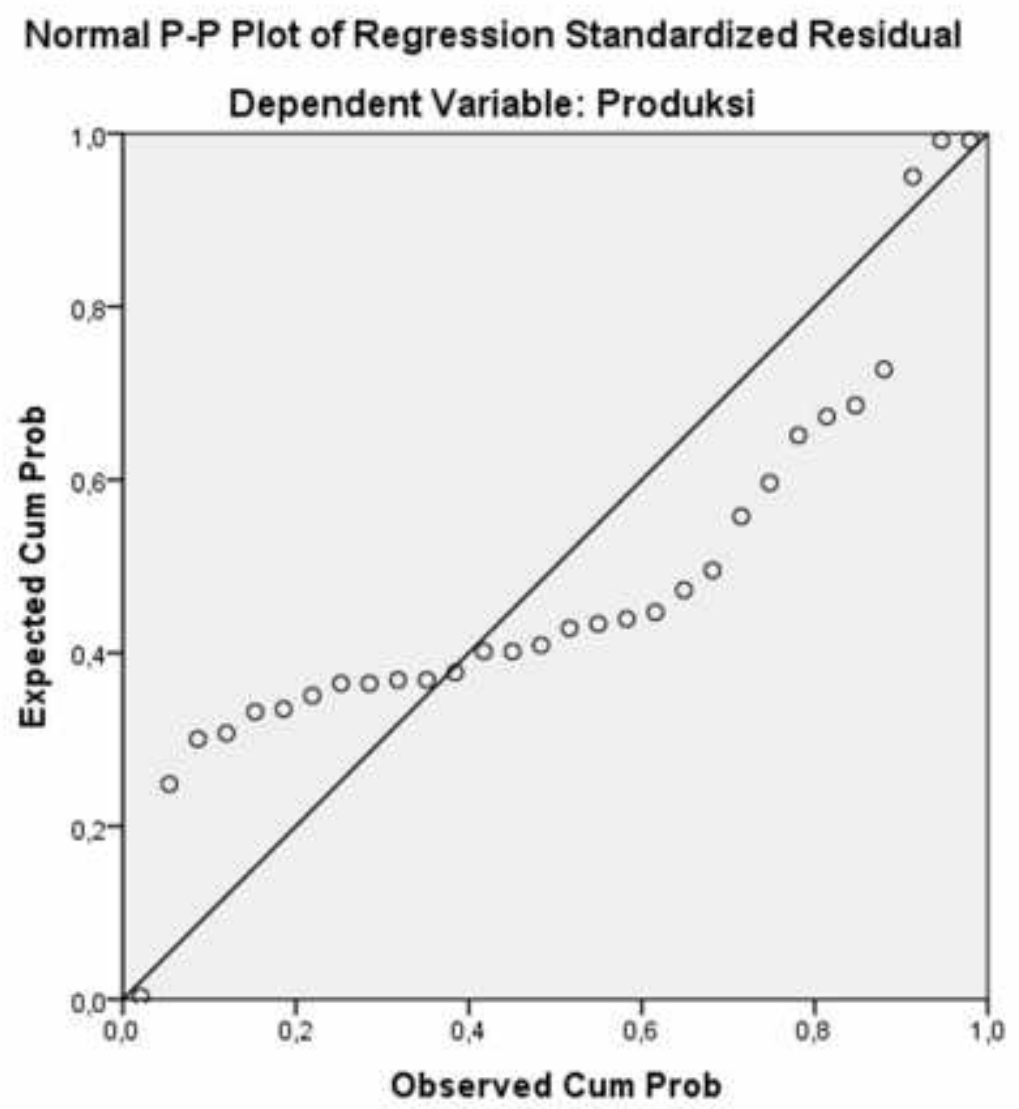

Sumber: Hasil Olahan Data, 2017

Gambar 2 di atas menunjukkan bahwa grafik Normal P-P of Regression Standardized Residual menggambarkan penyebaran data di sekitar garis diagonal dan penyebarannya mengikuti arah garis diagonal grafik tersebut, maka model regresi yang digunakan dalam penelitian ini masih cukup dalam memenuhi asumsi normalitas. 


\section{Uji Asumsi Klasik Heteroskesdastis}

Gambar 3 Uji Heteroskedastisitas

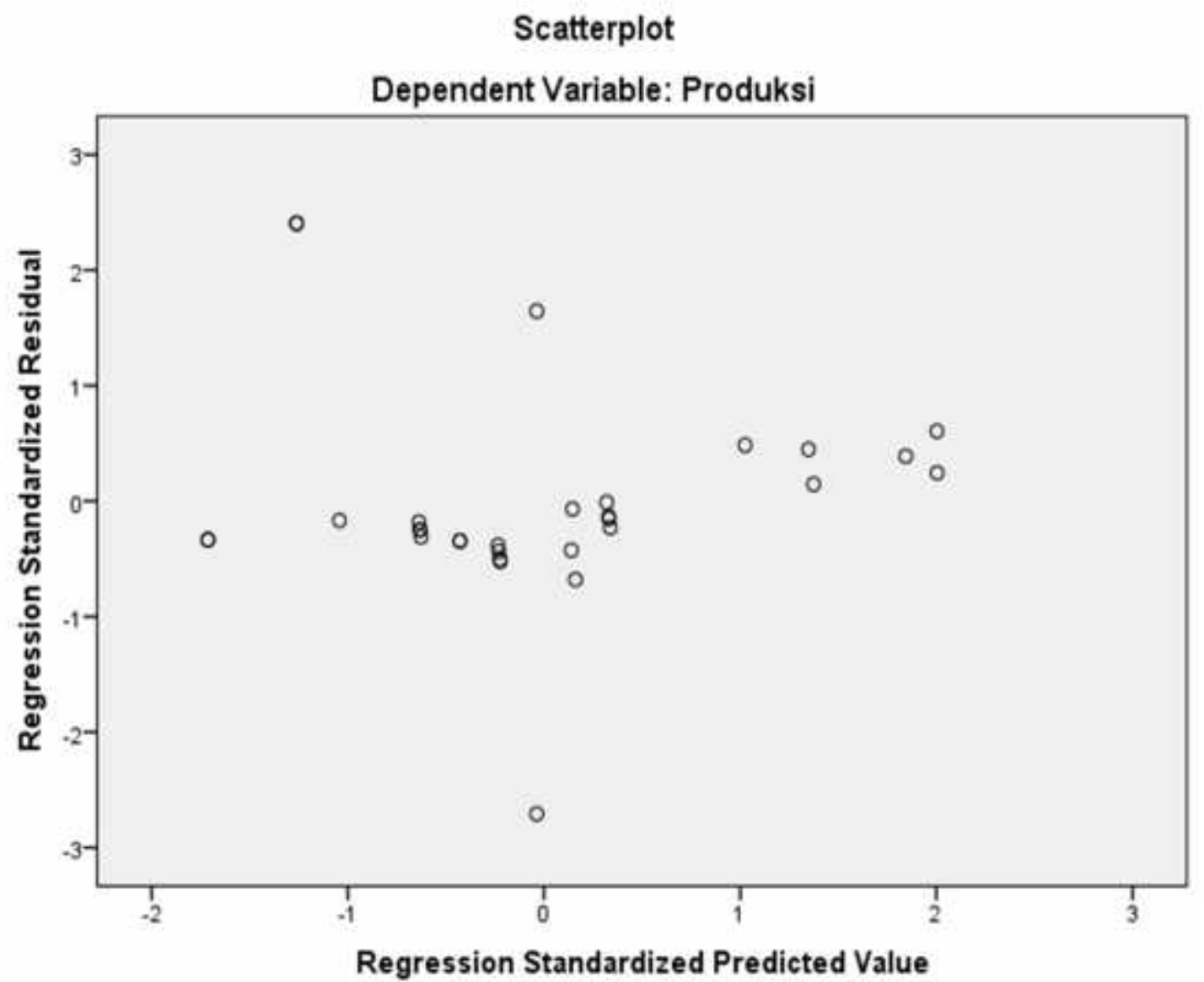

Sumber: Hasil Olahan Data, 2017

Gambar di atas (grafik Scatterplot) menunjukkan titik-titik yang menyebar secara acak dan tidak ada pola yang jelas terbentuk serta dalam penyebaran titik-titik tersebut menyebar dibawah dan diatas angka 0 pada sumbu Y. Hal tersebut mengidentifikasikan tidak terjadinya heterokesdastisitas pada model regresi, sehingga model regresi layak dipakai untuk memprediksi variabel produksi industri kecil (PIK).

\section{Analisis Regresi Berganda}

Dalam perhitungan regresi berganda dengan variabel terikat dengan variabel tak bebas Dengan menggunakan bantuan program SPSS windows maka, regresi yang diperoleh seperti terlihat pada bagian Coefficient dapat dijelaskan dalam Tabel 2. 


\section{Tabel 2. Hasil Analisis Regresi Berganda}

\begin{tabular}{|c|c|c|c|c|c|c|c|c|}
\hline \multicolumn{9}{|c|}{ Coefficients $^{\mathrm{a}}$} \\
\hline \multirow{2}{*}{\multicolumn{2}{|c|}{ Model }} & \multicolumn{2}{|c|}{$\begin{array}{c}\text { Unstandardized } \\
\text { Coefficients }\end{array}$} & \multirow{2}{*}{$\begin{array}{c}\text { Standardized } \\
\text { Coefficients } \\
\text { Beta } \\
\end{array}$} & \multirow[b]{2}{*}{$\mathrm{t}$} & \multirow[b]{2}{*}{ Sig. } & \multicolumn{2}{|c|}{ Collinearity Statistics } \\
\hline & & $\mathrm{B}$ & Std. Error & & & & Tolerance & VIF \\
\hline \multirow[t]{5}{*}{1} & (Constant) & 9,344 & ,310 & & 30,190 &, 000 & & \\
\hline & Modal Kerja &, 982 &, 106 & 1,013 & 9,281 &, 000 &, 021 & 8,091 \\
\hline & Bahan Baku & ,011 & , 102 &, 012 & 2,060 & ,004 & ,022 & 5,614 \\
\hline & Tenaga Kerja &, 002 &, 009 &, 004 & 2,229 &, 001 & ,789 & 1,267 \\
\hline & Pasar & ,002 &, 006 & ,007 & 2,377 &, 009 & ,756 & 1,323 \\
\hline
\end{tabular}

a. Dependent Variable: Produksi

Sumber: Hasil Olahan Data, 2017

Dari hasil analisis, diperoleh persamaan regresi linear berganda sebagai yaitu :

$\mathrm{PIK}=\log 9,344+\log 0,982 \mathrm{MK}+\log 0,011 \mathrm{BB}+\log 0,002 \mathrm{TK}+\log 0,002 \mathrm{P}+\varepsilon$.

Dari persamaan regresi linier berganda di atas, dapat menginformasikan bahwa :

1. Nilai konstan sebesar 9,344 artinya jika modal kerja, bahan baku, tenaga kerja, serta pasar yang diteliti, sama dengan nol (=0) maka produksi industri kecil olahan ikan Kota Manado sebesar 9,344.

2. Nilai koefisien regresi modal kerja sebesar 0,982 artinya, peningkatan modal kerja akan meningkatkan produksi industri kecil olahan ikan di Kota Manado sebesar 0,982 dengan asumsi faktor-faktor lain dianggap tetap.

3. Nilai koefisien regresi bahan baku sebesar 0,011 artinya, peningkatan bahan baku akan meningkatkan produksi industri kecil olahan ikan di Kota Manado sebesar 0,011 dengan asumsi faktor-faktor lain dianggap tetap.

4. Nilai koefisien regresi tenaga kerja sebesar 0,002 artinya, peningkatan tenaga kerja akan meningkatkan produksi industri kecil olahan ikan di Kota Manado sebesar 0,002 dengan asumsi faktor-faktor lain dianggap tetap.

Nilai koefisien regresi pasar sebesar 0,002 artinya, peningkatan pasar akan meningkatkan produksi industri kecil olahan ikan di Kota Manado sebesar 0,002 dengan asumsi faktor-faktor lain dianggap tetap.

\section{Uji Hipotesis Secara Parsial (Uji t)}

Uji hipotesis secara parsial digunakan untuk mengetahui pengaruh masing-masing variabel modal kerja, bahan baku, tenaga kerja, serta pasar terhadap produksi industri kecil olahan ikan di Kota Manado.

Berdasarkan hasil perhitungan yang dapat dilihat pada tabel 2 diperoleh hasil sebagai berikut :

1. Nilai $t_{\text {hitung }}$ untuk variabel modal kerja $(M K)$ sebesar 9,281 lebih besar dari nilai $t_{\text {tabel }}$ yaitu 2,059 dengan tingkat signifikan $0,000<0,05$ artinya variabel modal kerja berpengaruh signifikan terhadap produksi industri kecil olahan ikan di Kota Manado, ini berarti $\mathrm{H}_{\mathrm{a}}$ diterima.

2. Nilai $t_{\text {hitung }}$ untuk variabel bahan baku (BB) sebesar 2,060 lebih besar dari nilai $t_{\text {tabel }}$ yaitu 2,059 dengan tingkat signifikan $0,004<0,05$ artinya variabel bahan baku 
berpengaruh signifikan terhadap produksi industri kecil olahan ikan di Kota Manado, ini berarti $\mathrm{H}_{\mathrm{a}}$ diterima.

3. Nilai $t_{\text {hitung }}$ untuk variabel tenaga kerja (TK) sebesar 2,229 lebih besar dari nilai $t_{\text {tabel }}$ yaitu 2,059 dengan tingkat signifikan $0,001<0,05$ artinya variabel tenaga kerja berpengaruh signifikan terhadap produksi industri kecil olahan ikan di Kota Manado, ini berarti $\mathrm{H}_{\mathrm{a}}$ diterima.

Nilai $t_{\text {hitung }}$ untuk variabel pasar (P) sebesar 2,377 lebih besar dari nilai $t_{\text {tabel }}$ yaitu 2,059 dengan tingkat signifikan 0,009 $<0,05$ artinya variabel pasar berpengaruh signifikan terhadap produksi industri kecil olahan ikan di Kota Manado, ini berarti $\mathrm{H}_{\mathrm{a}}$ diterima.

\section{Uji Hipotesis Secara Simultan (Uji F)}

Untuk mengetahui pengaruh modal kerja, bahan baku, tenaga kerja dan pasar secara simultan terhadap produksi industri kecil olahan ikan di Kota Manado, maka dilakukan uji F. Uji hipotesis secara simultan menggunakan angka F sebagaimana tertera dalam tabel 3

\section{Tabel 3. Hasil Pengujian Hipotesis Secara Simultan} ANOVA $^{\mathrm{a}}$

\begin{tabular}{|ll|r|r|r|r|r|}
\hline Model & & Sum of Squares & \multicolumn{1}{c|}{ df } & Mean Square & F & Sig. \\
\hline 1 & Regression &, 352 & 4 &, 088 & 1002,528 &, $000^{\mathrm{D}}$ \\
& Residual &, 002 & 25 &, 000 & & \\
& Total &, 355 & 29 & & & \\
\hline
\end{tabular}

a. Dependent Variable: Produksi

b. Predictors: (Constant), Pasar, Tenaga Kerja, Bahan Baku, Modal Kerja

Sumber: Hasil Olahan Data, 2017

Pengujian dilakukan dengan cara membandingkan angka taraf signifikan hasil perhitungan dengan taraf signifikan 0,05 (5\%). Adapun langkah - langkah yang dilakukan dalam melakukan analisis hasil uji simultan (uji F) yaitu :

1) Merumuskan hipotesis

$\mathrm{H}_{0}$ : Modal kerja, bahan baku, tenaga kerja, dan pasar tidak berpengaruh terhadap produksi industri kecil olahan ikan Kota manado. $\left(\mathrm{B}_{1}, \mathrm{~B}_{2}, \mathrm{~B}_{3}, \mathrm{~B}_{4}=0\right)$

$\mathrm{H}_{\mathrm{a}}$ : $\quad$ Modal kerja, bahan baku, tenaga kerja, dan pasar berpengaruh terhadap produksi industri kecil olahan ikan Kota manado $\left(\mathrm{B}_{1}, \mathrm{~B}_{2}, \mathrm{~B}_{3}, \mathrm{~B}_{4} \neq 0\right)$.

2) Menentukan nilai kritis atau $F_{\text {tabel }}$

Dari tabel F (lampiran), diperoleh $\mathrm{F}_{\text {tabel }}$ adalah 2,742.

3) Menentukan $F_{\text {hitung }}$

Dari tabel 4.2 diperoleh $\mathrm{F}_{\text {hitung }}$ adalah 10002,528

4) Mengambil keputusan

Membandingkan $\mathrm{F}_{\text {hitung }}$ dengan $\mathrm{F}$ tabel dimana oleh karena 10002,528 > 2,742 maka $\mathrm{H}_{\mathrm{a}}$ diterima dan $\mathrm{H}_{0}$ ditolak.

Berdasarkan tingkat signifikansi, dimana dari tabel 3 diketahui tingkat signifikansi (Sig.) adalah 0,000. Oleh karena probabilitas 0,000 lebih kecil dari 0,05 maka $\mathrm{H}_{\mathrm{a}}$ diterima dan $\mathrm{H}_{0}$ ditolak.

5) Hasil uji simultan 
Berdasarkan langkah sebelumnya diketahui bahwa $\mathrm{H}_{\mathrm{a}}$ diterima dan $\mathrm{H}_{0}$ ditolak. Hal ini berarti modal kerja, bahan baku, tenaga kerja, dan pasar berpengaruh terhadap produksi industri kecil olahan ikan Kota manado.

Dengan demikian secara bersama-sama Modal kerja, bahan baku, tenaga kerja, dan pasar berpengaruh terhadap produksi industri kecil olahan ikan Kota manado, sehingga hipotesis yang menyatakan bahwa diduga modal kerja, bahan baku, tenaga kerja, dan pasar berpengaruh terhadap produksi industri kecil olahan ikan Kota Manado diterima.

\section{Koefisien Determinasi dan Korelasi}

Koefisien determinasi digunakan untuk mengetahui pengaruh seluruh variabel bebas (X) terhadap variabel terikat (Y), dan koefisien korelasi digunakan untuk mengetahui hubungan variabel bebas $(\mathrm{X})$ terhadap variabel terikat $(\mathrm{Y})$, dapat dilihat dalam tabel 4 sebagai berikut:

\section{Tabel 4. Koefisien Korelasi dan Determinasi}

\begin{tabular}{|l|r|r|r|r|r|}
\hline Model & $\mathrm{R}$ & $\mathrm{R}$ M Square & Adjusted R Square & $\begin{array}{c}\text { Std. Error of the } \\
\text { Estimate }\end{array}$ & Durbin-Watson \\
\hline 1 &, $997^{\mathrm{a}}$ &, 994 &, 993 &, 00937 & 2,612 \\
\hline
\end{tabular}

a. Predictors: (Constant), Pasar, Tenaga Kerja, Bahan Baku, Modal Kerja

b. Dependent Variable: Produksi

Sumber: Hasil Olahan Data, 2017

Berdasarkan hasil analisa korelasi ( $\mathrm{r}$ ) diperoleh nilai sebesar 0,997 hal ini menunjukkan bahwa hubungan antara modal kerja, bahan baku, tenaga kerja, dan pasar dengan produksi industri kecil olah ikan Kota Manado yaitu sebesar 99,7\%.

Berdasarkan hasil analisa determinasi $\left(\mathrm{R}^{2}\right)$ pada Tabel 3 diperoleh nilai sebesar $\mathrm{R}^{2}$ sebesar 0,994 atau 99,4\%. $\mathrm{R}^{2}=0,994$-> 99,4\% variasi Produksi Industri Kecil (PIK) dijelaskan oleh Modal Kerja (MK), Bahan Baku (BB), Tenaga Kerja (TK), dan Pasar (P), sedangkan 0,6\% variasi Produksi Industri Kecil (PIK) dijelaskan oleh variabel atau faktor-faktor lain di luar model penelitian.

\section{Pembahasan \\ Implikasi Hasil Penelitian}

Implikasi dari penelitian ini yaitu:

1. Produksi industri kecil (PIK) penting dalam peningkatan perekonomian suatu wilayah khususnya suatu daerah di Indonesia. Produksi industri kecil yang tinggi menandakan terjadinya efisiensi dari industri yang melakukan proses manufaktur input, proses dan output sumber-sumber daya yang ada.

2. Berdasarkan hasil penelitian ditemukan bahwa faktor-faktor produksi industri kecil olahan ikan di Kota Manado adalah modal kerja (MK), bahan baku (BB), tenaga kerja $(\mathrm{TK})$, serta pasar (P). Hal ini mengandung implikasi agar dapat dilakukan peningkatan secara bersama-sama dari keempat faktor tadi agar produksi industri kecil olahan ikan di Kota Manado dapat terus meningkat.

3. Modal kerja (MK) merupakan sejumlah dana yang dikeluarkan untuk memenuhi kebutuhan operasional industri. Dalam penelitian ini modal kerja berpengaruh terhadap produksi industri kecil olahan ikan di Kota Manado. Hasil ini sesuai dengan penelitian 
sebelumnya yaitu Bonanta (2016), Pratiwi, dkk (2010), Ismanto (2015), Duri (2016), Wijewerdana dan Zoysa (2012) yang menemukan bahwa modal kerja berpengaruh terhadap produksi manufaktur industri. Implikasi dari penelitian berarti bahwa jika dana yang dikeluarkan untuk memenuhi kebutuhan operasional industri tercukupi maka produksi industri kecil akan meningkat.

4. Bahan baku (BB) merupakan bahan utama dari produk atau barang. Dalam penelitian ini bahan baku berpengaruh terhadap produksi industri kecil olahan ikan di Kota Manado. Hasil ini sesuai dengan penelitian sebelumnya yaitu Aldida dan Santosa (2013), Bonanta (2016), Wulandari, dkk (2017), Surayah (2016), Pratiwi, dkk (2010), Ismanto (2015), yang menemukan bahwa bahan baku berpengaruh terhadap produksi manufaktur industri. Implikasi dari penelitian ini dimana peningkatan dari pasokan bahan utama untuk industri kecil pengoahan ikan di Kota Manado akan meningkatkan produksi industri kecil olahan ikan di Kota Manado.

5. Tenaga kerja (TK) merupakan mereka yang bekerja dalam industri dalam menghasikan barang atau produk. Dalam penelitian ini tenaga kerja berpengaruh terhadap produksi industri kecil olahan ikan di Kota Manado. Hasil ini sesuai dengan penelitian sebelumnya yaitu Aldida dan Santosa (2013), Bonanta (2016), Wulandari, dkk (2017), Gathura (2013), Suroyah (2016), Cahyanti dkk (2017), Duri (2016), Kader (2016). yang menemukan bahwa tenaga kerja berpengaruh terhadap produksi manufaktur industri. Implikasi dari penelitian ini yaitu jika orang-orang yang bekerja ditingkatkan jumlahnya pada industri kecil maka produksi industri kecil olahan ikan di Kota Manado akan meningkat.

6. Pasar $(\mathrm{P})$ merupakan suatu tempat atau proses interaksi pembelian dan penjualan barang dan jasa tertentu sehingga didapatkan harga pasar dan jumlah yang diperdagangkan. Dalam penelitian ini modal kerja berpengaruh terhadap produksi industri kecil olahan ikan di Kota Manado. Hasil ini sesuai dengan penelitian sebelumnya yaitu Shofa dan Navastra (2015), Gahtura (2013), Komppula (2014), Cahyanti dkk (2017), Kader (2012), Wijewerdana dan Zoysa (2012). yang menemukan bahwa pasar berpengaruh terhadap produksi manufaktur industri. Implikasi dari penelitian ini jika jumlah penjual atau pasar meningkat maka produksi juga akan meningkat khususnya dari produksi industri kecil olahan ikan di Kota Manado.

\section{Kesimpulan}

\section{KESIMPULAN DAN SARAN}

Adapun kesimpulan yang disimpulkan oleh penulis dalam penelitian ini sebagai berikut :

1. Variabel Modal Kerja (MK) berpengaruh positif dan signifikan terhadap Produksi Industri Kecil (PIK) pada industri kecil olahan ikan di Kota Manado.

2. Variabel Bahan Baku (BB) berpengaruh positif dan signifikan terhadap Produksi Industri Kecil (PIK) pada industri kecil olahan ikan di Kota Manado.

3. Variabel Tenaga Kerja (TK) berpengaruh positif dan signifikan terhadap Produksi Industri Kecil (PIK) pada industri kecil olahan ikan di Kota Manado.

4. Variabel Pasar (P) berpengaruh positif dan signifikan terhadap Produksi Industri Kecil (PIK) pada industri kecil olahan ikan di Kota Manado.

Variabel Modal Kerja (MK), Bahan Baku (BB), Tenaga Kerja (TK), dan Pasar (P) berpengaruh secara bersama-sama atau serentak terhadap Produksi Industri Kecil (PIK) pada industri kecil olahan ikan di Kota Manado 


\section{Saran}

Berdasarkan dari beberapa kesimpulan di atas maka dapat di berikan beberapa saran sebagai berikut :

1. Pemerintah Kota Manado atau instansi-instansi yang terkait agar dapat memberikan kemudahan dan fasilitas yang dapat merangsang peningkatan kegiatan di sektor industri kecil antara lain berupa modal kerja, peningkatan bahan baku, tenaga kerja, serta akses pasar yang pada akhirnya dapat meningkatkan tingkat produksi industri kecil olahan ikan di Kota Manado.

Para pengusaha industri kecil olahan ikan Kota Manado perlu fokus pada peningkatan modal kerja, perbaikan pasokan bahan baku, peningkatan kualitas dan kuantitas tenaga kerja serta memperluas akses pasar agar dapat meningkatkan produksi industri kecil olahan ikan di Kota Manado.

\section{DAFTAR PUSTAKA}

Aldida dan Santosa. 2013. Analisis Produksi dan Efisiensi Industri Kecil dan Menengah (IKM) Batik Tulis di Kota Semarang, Diponegoro Journal of Economics Volume 2, Nomor 1, Tahun 2013

Arsyad, Lincoln. 2010. Ekonomi Pembangunan, STIE YKPN Yogyakarta.

Assauri, Sofjan. (2000). Manajemen Pemasaran. Jakarta : Rajawali.

Bilas, Richard A. (2008). Teori Mikroekonomi. Erlangga: Jakarta.

Bonanta. 2016. Faktor-Faktor yang Mempengaruhi Produksi Industri Makanan di Provinsi Riau, Jurnal Ilmu Ekonomi Universitas Riau.

BPS. 2017. Konsep Industri. Jakarta: Badan Pusat Statistik Indonesia. Diunduh: https://www.bps.go.id/subjek/view/id/9. Diakses: 01 Maret 2017.

Cahyanti. 2017. Faktor-Faktor yang Mempengaruhi Perkembangan Usaha Kecil Sektor Industri Pengolahan di Kota Malang. Jurnal JIBEKA Volume 11 Nomor 2 Februari 2017:73-79.

Case \& Fair. (2007). Prinsip-Prinsip Ekonomi Mikro. (Y. Andri Zaimur. Terjemahan), Jakarta : Erlangga. Buku asli diterbitkan tahun 2006.

Duri. 2016. Modal dan Tenaga Kerja Pengaruhnya Terhadap Hasil Produksi Sepatu (Studi Kasus di Koperasi Produsen Sepatu Margosuryo Kota Mojokerto), Jurnal Pendidikan Ekonomi Vol 1. No 2, (2013), Universitas Negeri Surabaya.

Gujarati, Damodar N., 2003. Basic Econometrics, 4th Edition, Mc Graw Hill, New York.

Gathura. 2013. Factors affecting Small-Scale Coffee Production in Githunguri District, Kenya, International Journal of Academic Research in Business and Social Sciences, September 2013, Vol. 3, No. 9 ISSN: 2222-6990.

Ghozali, Imam. 2011. "Aplikasi Analisis Multivariate Dengan Program SPSS". Semarang, Badan Penerbit Universitas Diponegoro. 
Ismanto. 2015. Faktor-Faktor yang Mempengaruhi Produksi Industri Kecil di Kabupaten Kerinci, Jurnal Kajian Ekonomi, Juli, Vol III, No. 5.

Kader. 2009. Success Factors for Small Rural Entrepreneurs Under The One District One Industry Programme In Malaysia, Contemporary Management Research

Pages 147-162, Vol. 5, No. 2, June 2009, University of Malaya.

Komppula. 2004. Success Factors In Small And Micro Businesses - A Study Of Three Branches Of Industry In North Karelia, University of Joensuu Department of Business and Economics (Marketing), Discussion Papers No. 17, ISBN952-458-514-6 (pdf) ISSN 1458-686X.

Masiyal Kholmi, 2003 " A kuntasi Biaya", Edisi Empat, Yogyakarta, BPFE.

Mulyadi, 2005. Akuntansi Biaya. Edisi Kelima. Yogyakarta ; UPPAMP YKPN. Universitas Gajah Mada.

Nicholson, Walter, 1995, Teori Mikro Ekonomi, Prinsip Dasar dan Perluasan, Alih bahasa Daniel Wirajaya, 3

Pratiwi. 2010. Analisis Faktor-Faktor yang Mempengaruhi Produksi Industri Kecil Sepatu dan Konveksi di Kota Medan, Jurnal Mepa Ekonomi USU

Riyadi dan Deddy Supriyadi Bratakusumah. 2005. Perencanaan Pembangunan Daerah. Jakarta : PT Gramedia Pustaka Utama

Sukirno, Sadono.2010. Makro Ekonomi Modern: Perkembangan Pemikiran Dari Klasik Hingga Keynesian Baru. Raja Grafindo Persada. Jakarta.

Suprayitno, E. 2008. Ekonomi Mikro Perspektif Islam, Malang: UIN Malang Press.

Suroyah. 2016. Analisis Faktor-Faktor yang Mempengaruhi Nilai Industri Kecil Tenun Ikat di Kabupaten Jepara (Studi Troso Kecamatan Penanggungan Kabupaten Jepara), Jurnal Pendidikan dan Ekonomi, Volume 5, Nomor 1, Tahun 2016.

Suyadi Prawirosentono, 2001. Manajemen Operasi : Analisis dan Studi. Kasus,

Tambunan, T. 1999. Perkembangan Industri Skala Kecil di Indonesia. Jakarta: PT. Mutiara Sumber Widya.

Wijewerdana an Zoysa. 2005. A Factor Analytic Study of the Determinants of Success in Manufacturing SMEs, 35th EISB Conference - Sustaining the Entrepreneurial Spirit Over Time (pp. 1-11) Faculty of Business University of Wollongong Australia

Wulandari, Stiawina dan Djayastra. 2017. Analisis Faktor-Faktor yang Mempengaruhi Produksi Industri Perhiasan Logam Mulia di Kota Denpasar, E-Jurnal Ekonomi dan Bisnis Universitas Udayana 6.1 (2017): 79-108, ISSN : 2337-3067 